\title{
DE
}

DE GRUYTER

OPEN

Arch. Min. Sci., Vol. 61 (2016), No 3, p. 651-676

Electronic version (in color) of this paper is available: http://mining.archives.pl

DOI 10.1515/amsc-2016-0046

\author{
ILIE ONICA*, VIOREL MIHĂILESCU*, FELICIA ANDRIONI**
}

\section{ECONOMICAL OPTIMIZATION OF THE MECHANIZED LONGWALL FACES WITH TOP COAL CAVING MINING, IN HORIZONTAL SLICES}

\author{
OPTYMALIZACJA KOSZTÓW WYDOBYCIA ŚCIANOWEGO Z PROWADZENIEM STROPU \\ NA ZAWAL, PRZY WYBIERANIU WARSTWAMI POZIOMYMI
}

\begin{abstract}
To increase the economic and technical performances of the Jiu Valley hard coal mines, the top coal caving, in horizontal slices, mining methods (Bourbaki methods) were introduced, adapted to the local geo-mining conditions. This mining was successfully experimented by using classical technology, using the individual supports and coal blasting. In the future, it is planned to adopt the mechanized technology, with frame supports and shearers. The mechanized longwall faces with top coal caving mining, in horizontal slices, of coal seam no. 3 could be efficient only if the sizes of the top coal height and the panel length determine a minimum cost of production. Therefore, the goal of this paper is the optimization of these parameters, from a technical and economic point of view, taking into account the general model of the cost function, at the panel level. For that, it was necessary to make a certain sequence of analysis involving: technological unit establishment, purpose function and optimizing model. Thus, there attaining to the mathematical model of the unit cost, after determination of all the individual calculation articles, regarding the preparatory workings, coal face equipments, materials, energy, workforce, etc. Because of the complexity of the obtained technical and economic model, to determine the optimum sizes of the panel length and top coal height, it was necessary to archive a sensitivity analysis of the unit cost function to the main parameters implied into this mathematical model.
\end{abstract}

Kaywords: top coal caving mining, horizontal slice, parameters optimization, production cost, top coal height, panel length

W celu podniesienia wydajności i opłacalności wydobycia, w kopalniach węgla kamiennego w Dolinie Jiu wprowadzono metodę wybierania warstwami poziomymi, z prowadzeniem stropu na zawał (metoda Bourbaki), przystosowaną do panujących w terenie warunków geologicznych i górniczych. Wydobycie prowadzono z powodzeniem przy użyciu tradycyjnych technologii: prac strzałowych i systemu podpór. W przyszłości planuje się zastosowanie wybierania zmechanizowanego, z wykorzystaniem systemu

* UNIVERSITY OF PETROŞANI, MINING FACULTY, UNIVERSITY STREET, NO. 20, ROMANIA. E-mail: onicai2004@yahoo. com,vrlmih67@yahoo.com

** UNIVERSITY OF PETROŞANI, FACULTY OF SCIENCES, UNIVERSITY STREET, NO. 20, ROMANIA. E-mail: felicia_andrioni@yahoo.com 


\begin{abstract}
obudów oraz wrębiarek. Wybieranie ścianowe warstwami poziomymi w prowadzeniem stropu na zawał w przypadku pokładu nr 3 będzie efektywne jedynie wtedy, gdy odpowiednio dobrane zostaną wysokość węgla stropowego i długość pola wybierania, tak by zapewnić minimalne koszty wydobycia. Celem niniejszego opracowania jest optymalizacja tych parametrów, z uwzględnieniem aspektów technicznych i ekonomicznych, z wykorzystaniem ogólnego modelu funkcji kosztu dla danego poziomu pola wybierania. W tym celu przeprowadzono wieloetapową analizę, obejmującą określenie parametrów jednostkowych, funkcji celu oraz modelu optymalizacyjnego. Matematyczny model funkcji kosztu opracowano po uwzględnieniu niezbędnych do procedury obliczeniowej aspektów: prac przygotowawczych, analizy sprzętu używanego w rejonie przodka, materiały, energii, siły roboczej. Z uwagi na złożoność otrzymanego modelu technologicznego i ekonomicznego, aby obliczyć optymalny wymiar pola wybierania i wysokość węgla stropowego, niezbędne było przeprowadzenie analizy wrażliwości funkcji kosztu jednostkowego na zmiany podstawowych parametrów modelu.
\end{abstract}

Słowa kluczowe: wybierania na zawał, wybierania warstwami poziomymi, parametry optymalizacji, koszt wydobycia, wysokość węgla stropowego, długość pola wybierania

\title{
1. Generalities
}

The Jiu Valley is the most important coal basin from Romania, both considering the value of the balance reserves and of especial coke qualities of the western basin. Jiu Valley coal basin includes the following main units: Getic area, Autohton area and the sedimentary complex of the Petroşani basin with the Chattian level, which include the coal seams. The geological coal reserves of the basin are classified into the categories II and III, from the point of view of geological complexity, being intensively tectonized, with the important variation of the qualitative and quantitative parameters. The mining difficulties are amplified by the large emissions of methane and the coal self ignition tendency. Between the 22 identified coal seams, the coal seams no. 3 and 5 represent about $60 \%$ of the total coal reserves and the coal seam no. 3, $48 \%$ of the hard coal reserves, being present in all the mining fields. Coal seam no. 3 is situated at $25-50 \mathrm{~m}$ distance from the Rupellian-Chatian limits. It has variable thickness, ranging between $0.5 \mathrm{~m}$ and $34 \mathrm{~m}$, in some places even $50 \mathrm{~m}$, with large differences following the strike and the dip. The appreciable thickness may be encountered in the mining perimeters Lonea, Petrila, Dâlja, Aninoasa, Vulcan and Lupeni (Almăşan, 1984; Onica, 1995; Onica \& Marian, 2012).

Generally, in the mining fields situated in the eastern half of the coal basin, the coal seam has the largest thickness. The coal seam no. 3 is consisted by three carbonaceous intercalations, separated by dark grey clays, more compacted in the upper zone and more non-homogeneous toward the floor, disposed in two complexes. The stratigraphical characteristic of the coal seam no. 3 is its wedging out and its substitution into a gray-greenish, shandy-shale rocks complex, on the eastern side of the basin, starting with the Paroșeni perimeter. The coal seam no. 3 roof consists of argillaceous sandstones or limestone, very well cemented, with alternation of shandy-shale and traces of plants, and the floor consists of sandstones with sideritic concretions (Almăşan, 1984; Onica, 1995; Onica \& Marian, 2012).

The geometrical characteristics of the coal seam no. 3, the irregular shape of the coal bodies, complicated tectonics which had fractured the coal deposits into several geologic blocks with reduced strike sizes (Fig. 1), are the difficulties that led to the impossibility to efficiently mechanize the mining of the coal seam no. 3 . 


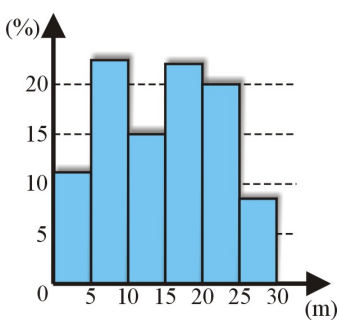

a)

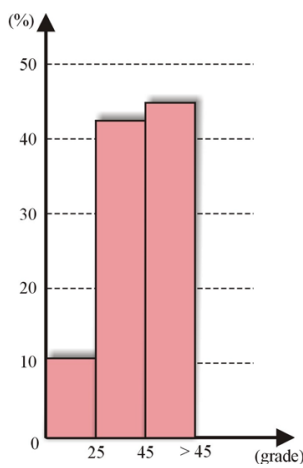

b)

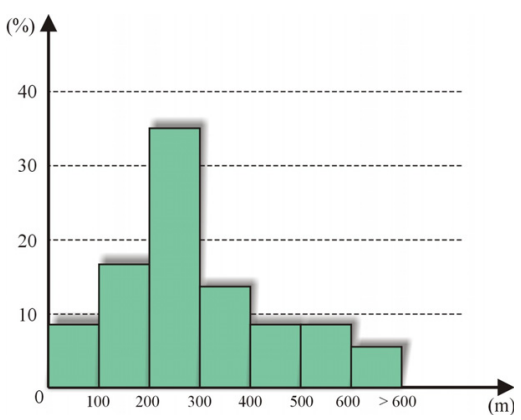

c)

Fig. 1. Histograms of the main geometrical characteristics of the coal seam no. 3 - Jiu Valley coal basin: a) thicknesses; b) dips; c) block lengths (Onica, 1995)

Romania's accession to the European Union imposed compliance with the European rules and regulations, in the hard coal mining area as well. A correct assessment of the future evolution, concerning the coal mining in the Jiu Valley coal basin, must take into account the imposed constraints by the economic efficiency of the mining and the environmental ones (Mihăilescu, 2014).

The evolution of total coal production, mined and processed, obtained at the whole coal basin, in the period 2007-2011, is shown in Figure 2 and in the case of every mining method, in Figure 3. Analysing the data, represented in the graphics, the following conclusions result: production has a decreasing tendency, the coal quantity extracted at the end of year 2011 is less than $20 \%$ by report to 2007 ; the net coal quantity, processed and delivered, at the end of 2011 is less than 463,940 tonnes, by report to year 2007 (decrease being 23.3\%).

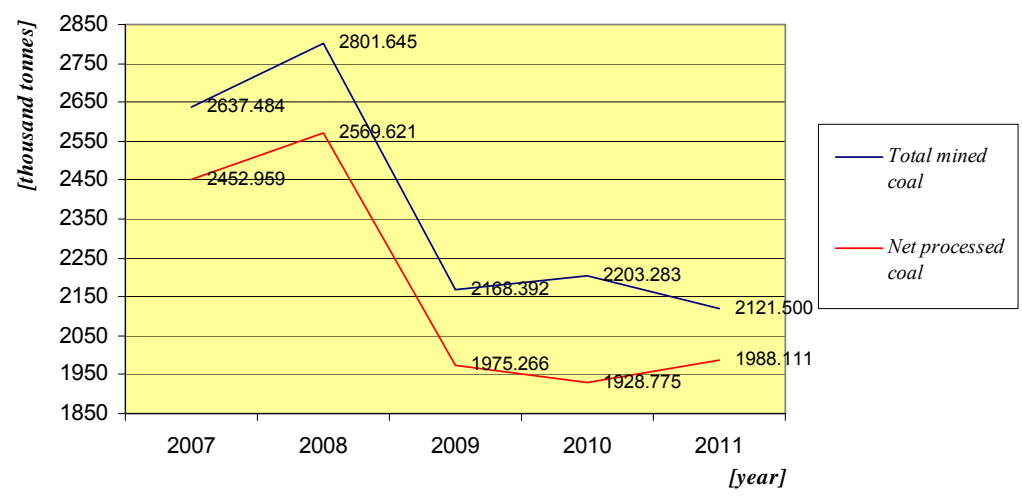

Fig. 2. Total net coal production, mined and processed, obtained at the coal basin level

The causes that led to that situation are mainly political and technical - economic. Thus, in the category of the political causes could be included, easily, the European Commission Regulation (EC) no.1407/2002, regarding the state aid for coal industry, which led to the continuous 
decrease of the Romanian state subsidy for the hard coal producers and the Council Decision 2010/787/EU, regarding the state aid for the closure facility of non-competitive coal mines (Mihăilescu, 2014). Also, interests regarding the increasing efficiency of the coal deposits exist throughout the EU, especially in central and eastern European countries (Jonek-Kowalska, 2012, 2013; Jonek-Kowalska \& Turek, 2013).

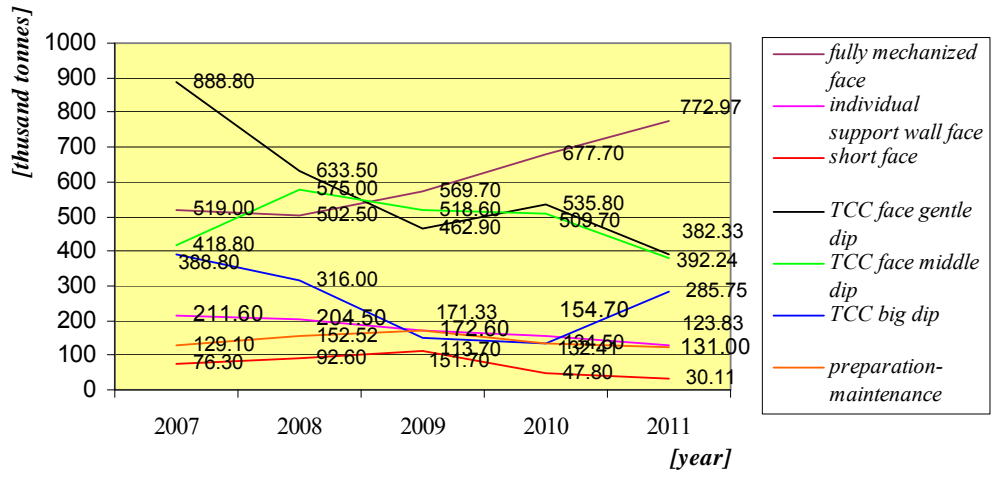

Fig. 3. Achieved production, in the case every mining method, for entire coal basin

Among the technical-economic causes that determined the diminution of the coal production at the coal basin level are the ones listed below:

- reduction of the production capacities by incompliance with the openings and preparatory underground workings programme, established by the annual mining plans and by their depletion;

- reduction of the coal demand from the internal market - the main customers being the power-stations of Paroşeni and Mintia;

- inability to provide optimal covering with workers, for the working faces. The absonant placement of the miners in the faces determined the reduction of the daily advancement speed of the coal faces, increasing the production period cycle and, implicitly, increasing the period of the stress concentration acting on the supports of faces and of preparatory galleries- resulting the supports deterioration and an important degradation of the top coal and major difficulties regarding the rock roof control operation;

- technical accidents (rocks failures, malfunctions of the cutting machines, etc) that led to the increase of the stagnation periods of the faces and a corresponding reduction of the coal production;

- two work accidents, with casualties, produced at the Petrila mine, in the trimester IV, 2008 and at the Uricani mine, in the trimester II, 2010, accidents that led to the closing of the production capacities and the labour relocation toward the rehabilitation of the accident's consequences.

Jiu Valley demographic rate is fluctuating and difficult to follow because of the comings and goings percentage of population to suggest the image of transit zones, even if mining companies were closed, and a lack of other employment alternatives (Andrioni \& Schmidt, 2011). Successive stages of economic restructuring operate at the Hunedoara County and Jiu Valley area, the lack 
of viable investment alternatives are continuously generated a major negative impact among the population. Economic consequences have been fully reflected on the social increased poverty in the area damaging the quality of life. These negative aspects have induced an accumulated economic and psychological discomfort to the individual level (Andrioni \& Goian, 2012).

Among others, a taken measure for increasing the economic efficiency of the coal mining in this basin is the introduction of the top coal caving mining methods, first for the medium and gentle inclined seams of the coal seam no. 3, and later for the thick and dip coal seams (Onica, 1990; Onica \& Chiril, 2005).

In the geo-mining conditions of Jiu Valley thick coal seams, the use of top coal caving mining methods led to a substantial increase of obtained coal production by report to the classical mining methods, in slices (Covaci, 1983; Onica \& Chiril, 2005; Onica et al., 2011), and the productivity approaching the values obtained from fully mechanized faces.

In that direction, in the following, the technical and economic optimization of the main parameters of the top coal caving mining method, in horizontal slices, used for the thick and dip coal seams, will be presented.

The goal of this study is the determination of the optimum interval in which, the parameters taken into calculus (mainly, the top coal height and the straight panel length) satisfies a minimum cost, at the panel level (Chiril, 2001; Onica \& Chiril, 2005).

\section{Establishment of the technological unit for optimization}

Specifically for the mining industry, the operating process obeys the same economical laws as any industrial process. Their modelling respects the following scheme: $X\{\rightarrow[S] \rightarrow\} Y$; where: $Y=\left(y_{i}\right)$ is the system's outputs volume, $i=\overline{1, n} ; X=\left(x_{i}\right)$ - the qualitative and quantitative factors that influence the system's outputs $y_{i}, i=\overline{1, m} ; S$ - system structure through the factors $x_{i}$ that influence the outputs $y_{i}$ (Mihăilescu et al., 2012, 2013).

A mining operating process could be represented, schematically (Fig. 4), by a series of sets as: the consumption factors that enter in the process $X=\left\{x_{1}, x_{2}, \ldots, x_{n}\right\}$; the rules that the time development follows $L=\left\{l_{1}, l_{2}, \ldots, l_{k}\right\}$; the mining products (the production factors that are coming out of the process) $Y=\left\{y_{1}, y_{2}, \ldots, y_{m}\right\}$ and the several perturbation factors $U=\left\{u_{1}, u_{2}, \ldots, u_{p}\right\}$ (Mihăilescu et al., 2012, 2013).

Analysing the mining method (Fig. 5) and mining technology (Fig. 6) for the thick coal seams, it is observed that they are characterized by a series of parameters classified into 3 importance groups, as in:

a) Main parameters: represent the panel elements and those that are determined based on their interdependences, some auxiliary parameters and the technical and economical indicators;

b) Auxiliary parameters: determine or are determined from main parameters in function of the applied technological variant specificity and have a determined role in the mining method economy;

c) Specific parameters: are specifically only for a certain mining variant or method and have an influence, especially, on the labour productivity at the coal cutting, loading and exhaustion. 


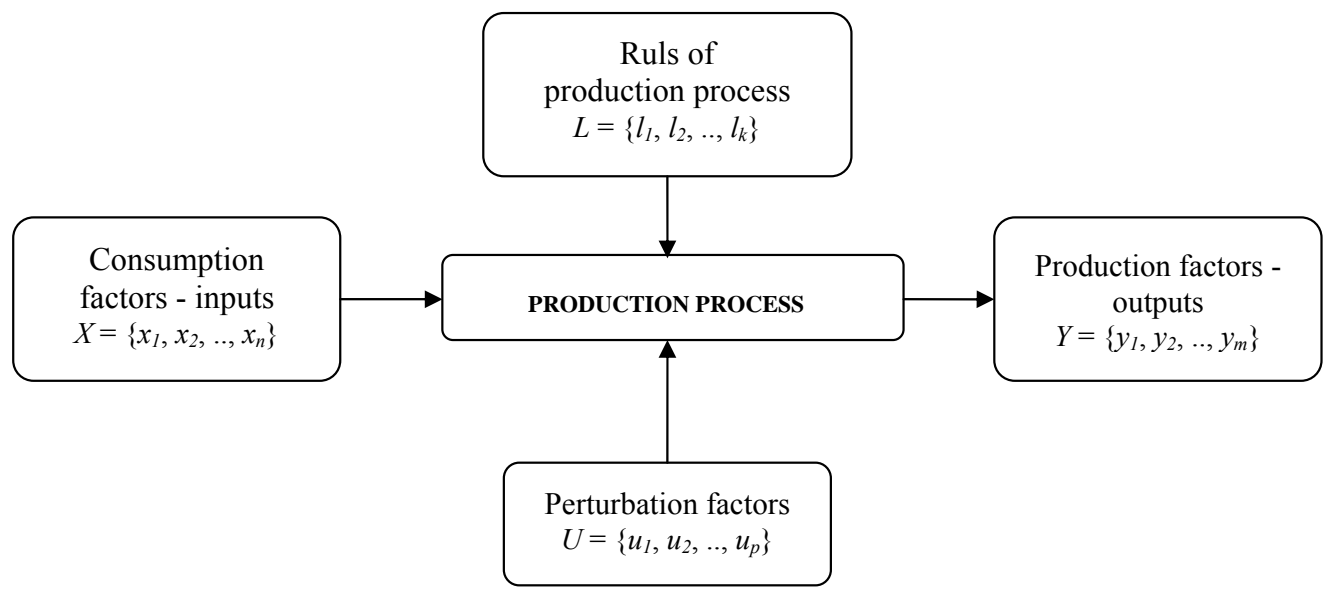

Fig. 4. Principle schema of the production process
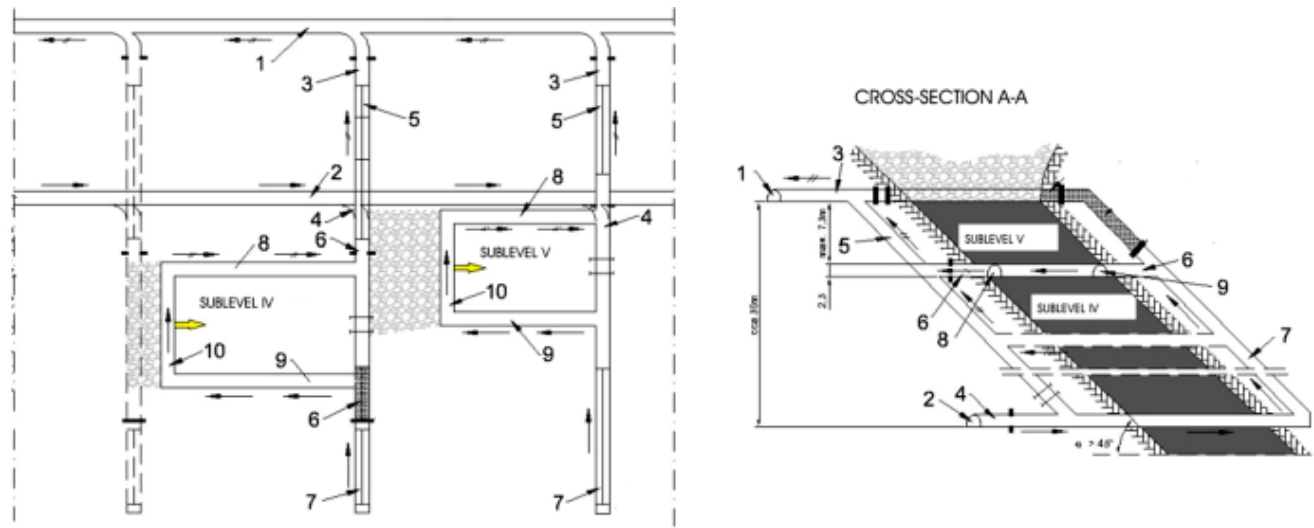

FRONT ELEVATION
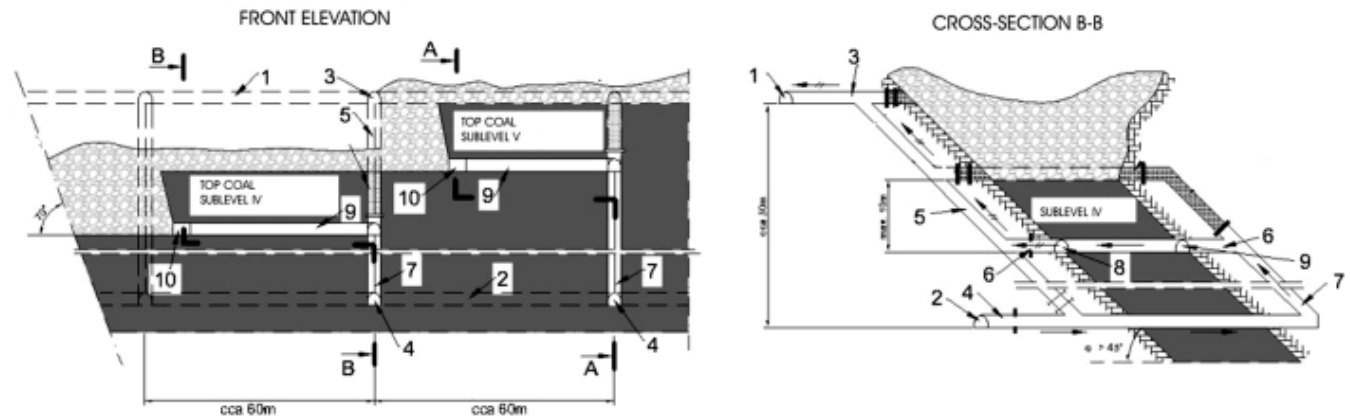

Fig. 5. Longwall faces top coal caving mining method, in horizontal slices, applied at the coal seam no. 3 , for the dip of $\geq 45^{\circ}$

$1 / 2$ - transport/ventilation directionally gallery; $3 / 4$ - transport/ventilation panel cross-cut gallery; 5 - transport raise; 6 - short cross-cut gallery; 7 - ventilation raise; $8 / 9$ - transport /ventilation preparatory strike gallery; 10 - longwall face with top coal caving 
The main variable parameters that characterise this compound of the mining unit and which must be optimized are the panel length $\left(l_{c a}\right)$ and the top coal caving height $\left(h_{b}\right)$.

The criteria used in the optimization problem solving are the following: the cost of the unit product $c(c \rightarrow \min )$; the output capacity $P(P \rightarrow \max )$ and the labour consumption $M(M \rightarrow \min )$ (Chiril, 2001; Onica \& Chiril, 2005; Jaszczuk \& Kania, 2008).

For solving the mathematical and economical models, resulted from the applied certain programming method, only one optimization criterion is taken into consideration, for the other ones being imposed restrictions (Chiril, 2001; Onica \& Chiril, 2005), thus:

- if the used basis criterion is the cost of the product unit (lei/tonne) then the purpose function has the form: $C \rightarrow \min$, with the restrictions: $P \geq P_{\text {plan }}$ and $M \leq M_{\text {admis }}$;

- if the output and the labour consumption are considered as a basis criterion, then: $P \rightarrow \max$, $M \rightarrow \min$, with the restriction: $c \leq c_{\text {plan }}$ (where: plan - targeted; admis-admissible).

The longwall face mining method, with top coal caving (Onica \& Chiril, 2005), in horizontal slices (in conformity with the framework project) is shown in the Figure 5.

The longwall face with top coal caving detain the following equipments: frame powered supports type GEROM GP 250/1200 of indigenous production (Fig. 2); coal shearer type ESA 60 L; conveyor type TR-7A, on the coal face line and (in certain technological cases) a rear conveyor TR-3, for caved coal.

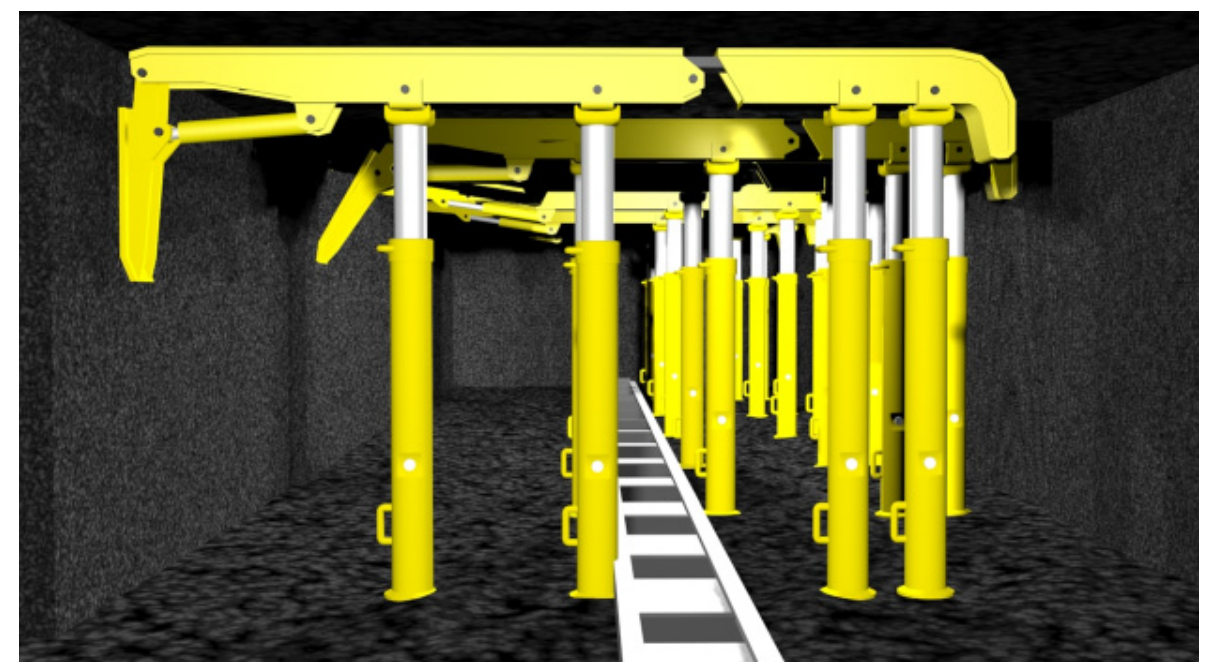

Fig. 6. Frame powered supports type GEROM GP 250/12

\section{Establishment of the purpose function of the optimizing model}

At the level of the mining economical units, the cost product on the primary cost elements has the following structure: 1) raw, basic and auxiliary materials; 2) fuel; 3) energy and water; 4) depreciation and fixed assets; 5 ) other material costs; 6$)$ total materials costs $(1 \rightarrow 15)$; 7$)$ salaries; 
8) insurances and social protection; 9) other labour costs (including the recovery of the geological researches); 10) total labour costs $(7 \rightarrow 9)$; 11) total costs $(6+10)$ (Mihăilescu, 2014).

Total coal mining costs are defined as an amount of the average costs generated in the frame of every technological process stage (panel preparation, coal face extraction, coal transport) and for the establishment of their volume are applied the provisions relating to consumption's calculation sheets, tariffs and unit consumptions, rules and normative for mining industry, effective expenses achieved by the mines.

In the following mathematical models, the casual cost due to hazards (coal self-ignitions, methane explosions, rock fall-downs, technical accidents, etc), being the random events, was not taken into consideration at the panel level, these being involved in the mine level cost.

Thus, the general form of the optimization criterion is:

$$
c_{i}=\frac{\sum C_{i}}{R_{e}}, \text { in lei/tonne }
$$

1 leu (plural "lei") - the basic unit of money in Romania; 1 euro $\cong 4.5$ lei-year 2014 .

Where: $c$ represents the unit cost of the coal mining at the longwall face level, in lei/tonne; $\sum C_{i}$ - the total costs, in lei; $R_{e}$ - the industrial coal reserves of the mining panel, in tonnes.

The panel industrial coal reserves are calculated with the relation:

$$
R_{e}=l_{c a} \cdot \frac{m}{\sin \alpha} \cdot\left(h_{a b}+h_{b}\right) \cdot \rho \cdot k_{1}, \text { in tonne }
$$

Where: $l_{c a}$ represents the panel length, in $\mathrm{m} ; l_{a b}=\frac{m}{\sin \alpha}$ - longwall face length, in $\mathrm{m} ; m$ - normal thickness of the coal seam, in $\mathrm{m} ; \alpha$ - coal seam dip, in ${ }^{\circ} ; h_{a b}$ - face height, in $\mathrm{m} ; h_{b}-$ top coal height, in $\mathrm{m} ; \rho$ - coal apparent specific density, in tonne $/ \mathrm{m}^{3} ; k_{1}=\frac{\eta}{1-D}-$ coefficient that takes into consideration the recovery factor $\eta$ and the dilution factor $D$.

The mathematical model of the general costs, elaborated for the longwall face with top coal caving, in horizontal slices, as a basic technological unit, contains all the average cost categories effectuated for the coal mining at the panel level (Chiril, 2001; Onica \& Chiril, 2005; Mihăilescu et al, 2013; Mihăilescu, 2014):

$$
\sum C=\sum P+\sum I+\sum U+\sum M+\sum E+\sum A, \text { in lei }
$$

Where: $\sum C$ represents the total costs effectuated at the panel level, in lei; $\sum P$ - preparatory workings costs, in lei; $\sum I$ - preparatory working maintenance costs, in lei; $\sum U$ - longwall equipments (cutting, support and transportation) costs in lei; $\sum M$ - labour costs, in lei; $\sum E$ - energy (electrical, pneumatic) costs, in lei; $\sum A$ - auxiliary costs (equipment maintenance, materials - wire mesh, wood, explosive material), in lei. 


\section{Mathematical model of the unit cost, afferent to the longwall face with top coal caving mining}

\subsection{Preparatory workings costs}

\subsubsection{Preparatory workings construction costs}

The preparatory working scheme, afferent for the panel represented in the Figure 5, is composed of the following workings: transport preparatory strike gallery, on the coal floor, driven on the panel length $l_{c a}$; ventilation preparatory strike gallery, under the coal roof, driven on the panel length $l_{c a}$; starting face preparatory gallery, with the face length $l_{a b}$; raises between the cross-cut galleries, at the minimum $10 \mathrm{~m}$ distance from the coal seam floor, with the length equal to $l_{s c}=\frac{h_{a b}+h_{b}}{\sin \alpha}$; raises between the cross-cut galleries, inside the coal seam roof, with the length equal to $l_{s a}=\frac{h_{a b}+h_{b}}{\sin \alpha}$; short cross-cut galleries, at the slices level, with the length about $10 \mathrm{~m}$; transport/ventilation directionally galleries, driven in the rocks, with the length of $l_{c a}$; transport/ventilation panel cross-cut galleries, with the length about $10 \mathrm{~m}$.

The quantification of the achieved costs for the panel preparation is linked from the transversal section, support and arrangement of the preparatory workings (depending on the role of every working). The starting face workings will be driven with the same section with the two directional preparatory galleries, but with the additionally costs generated by the face equipment mounting. Also, the raises have a circular shape with a cross section of $6.25 \mathrm{~m}^{2}$.

Because of the difficult conditions of the coal mines, recovering and reusing certain materials, as preparatory workings supports elements, are impossible or difficult to be provided and with huge costs, surpassing their purchase values.

Taking into account of these aspects, the relation that quantifies the costs generated by the construction of the preparatory workings is:

$$
\sum P=\left(2 \cdot l_{c a} \cdot k_{g}+2 \cdot \frac{l_{c a}}{60} \cdot l_{g t i} \cdot k_{g}\right)+l_{a b} \cdot k_{p a}+2 \cdot \frac{l_{c a}}{60} \cdot l_{s a / s c} \cdot k_{s}+K_{m d} \text {, in lei }
$$

Where: $l_{c a}$ is the length of the transport/ventilation preparatory workings driven at the slice level, in $\mathrm{m} ; k_{g}$ - unit cost of the previous workings, in lei/m; first term $2 \cdot \frac{l_{c a}}{60}-$ number of the cross-cut galleries driven from the transport/ventilation raises - in the floor, respectively in the roof (see the Fig. 5: 2 is two raises; $60 \mathrm{~m}$-distance between two successive raises); $l_{g t i}=10 \mathrm{~m}-$ length of the panel cross-cut galleries; $l_{a b}=\frac{m}{\sin \alpha}$ - face length, in $\mathrm{m} ; m$ - coal seam thickness, in $\mathrm{m}$; $\alpha$ - coal seam dip, in ${ }^{\circ} ; k_{p a}$ - unit cost for construction of the starting gallery, in lei/m; second term $2 \cdot \frac{l_{c a}}{60}$ - counting number of raises driven in the rocks floor and roof; $k_{s}$ - unit cost for raise construction, in lei/m; $l_{s a}$ - length of the intermediary panel roof raise, in $\mathrm{m} ; l_{s c}$ - length of the intermediary panel floor raise, in $\mathrm{m}$. 


$$
\begin{gathered}
l_{s a}=l_{s c}=\frac{h_{a b}+h_{b}}{\sin \alpha}, \text { in } \mathrm{m} \\
K_{m d}=1976.08 \cdot \frac{m}{\sin \alpha}+6.36 \cdot\left(\frac{m}{\sin \alpha}\right)^{2}+11343.83, \text { in lei }
\end{gathered}
$$

Where: $K_{m d}$ - represents the powered supports units mounting and demounting cost, afferents to the operating mining face.

Replacing the parameters values, in the previous relation, results:

$$
\begin{aligned}
\sum P= & l_{c a} \cdot\left(2.33 \cdot k_{g}+0.033 \cdot \frac{h_{a b}+h_{b}}{\sin \alpha} \cdot k_{s}\right)+\frac{m}{\sin \alpha} \cdot k_{p a}+ \\
& +1976.08 \cdot \frac{m}{\sin \alpha}+6.36 \cdot\left(\frac{m}{\sin \alpha}\right)^{2}+11343.83
\end{aligned}
$$

\subsubsection{Cost of the preparatory workings maintenance}

The size of the maintenance cost of the preparatory workings, afferents to the panel, depending on the time of the preparation and mining of the panel slice coal reserve. As coal reserve is mined, the slice preparatory galleries are reduced and the rises length remains constant during the slice mining period. The exact assessment of these costs is practically very difficult because the various spatial conditions of the coal seam and the variable stress and strain states, depending on the mining level.

From the financial data analysis, existed at the mines, results that the maintenance value ranges from $10-15 \%$ (for easy conditions) to $80-100 \%$ (for heavy conditions) from the construction value of the preparatory workings.

Thus, the relation that quantifies the maintenance cost of the preparatory workings has the following form:

$$
\sum I=k_{i} \cdot \sum P \cdot T_{e x}, \text { in lei }
$$

Where: $k_{i}$ is a coefficient of the weighting of the annual maintenance cost in the total preparatory working construction cost $k_{i} \cdot \sum P$ - total annual maintenance cost of the preparatory workings, in lei/year.

The daily coal production is calculated with following relation:

$$
P_{z}=k_{1} \cdot \rho \cdot v_{m} \cdot \frac{m}{\sin \alpha} \cdot\left(h_{a b}+h_{b}\right) \text {, in tonne/day }
$$

Where: $v_{m}$ represents the average daily advancement speed of the coal face, in $\mathrm{m} /$ day; $\rho$ - coal specific density, in tonne $/ \mathrm{m}^{3}$.

The panel mining period $T_{e x}$ could be determined with the formula:

$$
T_{e x}=\frac{l_{c a}}{N \cdot v_{m}}=\frac{l_{c a}}{256 \cdot v_{m}}, \text { in years }
$$

$N=256$ days - the average number of the working days at the coal mine basin level. 
Finally, the calculus equation of the maintenance preparatory workings cost is:

$$
\sum I=\frac{1}{v_{m}} \cdot l_{c a}^{2} \cdot\left[6.81 \cdot 10^{-4} \cdot k_{g}+9.9 \cdot 10^{-3} \cdot\left(\frac{h_{a b}+h_{b}}{\sin \alpha}\right) \cdot k_{s}\right], \text { in lei }
$$

\subsection{Mining equipment cost equation}

The mining equipment used in the coal faces are the followings: cutting machines: shearer Eickhoff ESA-60L (made in Germany); powered supports: frame supports GEROM GP 2500/1200 (made in Romania); conveyors: TR-5 or TR-7A (at the coal face), TR-3 (at the top coal caving and on the slice transport gallery) - also, made in Romania.

Regarding the coal face equipment (powered supports, cutting machines, conveyers, etc), these could be purchased or taken by leasing. Because of the destruction risk of the mining equipment in the very difficult underground conditions, the mining company policy is to purchase the equipment.

Thus, the depreciation cost of the equipments is done by the relation:

$$
\sum U=\sum A_{a} \cdot T_{e x}=\sum \frac{V_{i}}{d_{i}} \cdot T_{e x}, \text { in lei }
$$

Where: $\sum A_{a}$ represents the amount of the depreciation annually rate of the coal face equipments; $T_{e x}-$ mining period of the coal panel, in years.

- Acquisition price of the cutting machine:

$$
V_{t}=n_{u t} \cdot k_{u t}, \text { in lei }
$$

Where: $k_{u t}$ represents the value of the supports equipments used in the coal face, in lei; $n_{u t}$ - number of cutting machines.

- Acquisition price of the face supports units:

Number of the face support units is established with the relation:

$$
n_{s}=\frac{\frac{m}{\sin \alpha}}{l_{s}}=1.25 \cdot \frac{m}{\sin \alpha}, \text { in support units }
$$

- Acquisition value of the entire face supports is:

$$
V_{s}=1.25 \cdot \frac{m}{\sin \alpha} \cdot k_{c s}, \text { in lei }
$$

Where: $l_{s}$ - distance between two adjacent frame supports, in $\mathrm{m} ; k_{s}$ represents the price of a support unit, in lei.

- Acquisition price of the conveyors:

$$
V_{t p}=n_{1} \cdot k_{t a}+k_{t g}, \text { in lei }
$$

$n_{1}$ is the number of the coal face conveyors; $k_{t a}$ - price of the coal face conveyor; $k_{t g}$ - price of preparatory working conveyor. 
The annually depreciation assets, concerning the coal face equipments $\left(A_{a}\right)$, is calculated with the relation:

$$
A_{a}=\frac{V_{i}}{d_{i}}, \text { in lei/year }
$$

Where: $V_{i}$ - depreciable value of the coal face equipments, in lei; $d_{i}-$ depreciation period of every equipment, in years.

The cost generated by the equipment use is:

$$
\sum U=\sum A_{a} \cdot T_{e x}=\sum \frac{V_{i}}{d_{i}} \cdot T_{e x}=\frac{l_{c a}}{256 \cdot v_{m}} \cdot\left(\frac{V_{t}}{d_{1}}+\frac{V_{s}}{d_{2}}+\frac{V_{t p}}{d_{3}}\right), \text { in lei }
$$

By replacing certain previous parameters, the relation becomes:

$$
\sum U=\frac{l_{c a}}{256 \cdot v_{m}} \cdot\left(\frac{k_{u t}}{d_{1}}+1.25 \cdot \frac{m}{\sin \alpha} \cdot \frac{k_{c s}}{d_{2}}+\frac{n_{1} \cdot k_{t a}+k_{t g}}{d_{3}}\right), \text { in lei }
$$

\subsection{Labour cost of coal reserve mining}

It is equivalent to the costs generated by the labour force, operating in the coal face, during the mining of the coal panel reserve.

To quantify the labour cost, it is necessary to make the production process analysis at the coal face level, in view to establish the lifecycle of production process and the daily advancement speed of the coal face.

This analysis supposes the browsing of the following sequences:

- determination of the basis of organisation that involves the identification of the technical, technological and organisational data, having an influence on the production process;

- simple production process analysis, determining the time and work rules of these, in view to found the production lifecycle.

In the calculus, the direct salary is increased with a coefficient equal to 2.185 , taking into account the different wages and benefits provided by the actual legislation, regarding the coal mining activity.

The equation that explains the working consumption in the coal face is the following:

$$
n \cdot t=\sum M
$$

Where: $n$ represents the shift workers number in the coal face; $t=360 \mathrm{~min}-$ life shift; $\sum M-$ sum of work consumption of the operations developed in the coal face to provide a coal production cycle for an advancement step of $1.25 \mathrm{~m}$.

$$
\sum M=M_{01}+M_{02}+\ldots . .+M_{12}, \text { in worker } \cdot \text { minutes/cycle }
$$


Total work consumption, necessary for a complete coal production cycle, is calculated with the relation:

$$
\sum M=2067.11+66.02 \cdot \frac{m}{\sin \alpha}+16.55 \cdot \frac{m}{\sin \alpha} \cdot h_{b}+66.2 \cdot h_{b}+15 \cdot n
$$

From the production process analysis there is established the shift number, necessary for coal face advancement with a step equal to $w_{c}=1.25 \mathrm{~m}$ :

$$
n_{c}=0.18 \cdot \frac{m}{\sin \alpha}+0.045 \cdot \frac{m}{\sin \alpha} \cdot h_{b}+0.18 \cdot h_{b}+5.74, \text { in worker } . \text { shift } / \text { cycle }
$$

Total shift number, necessary to mining the coal reserve of the panel, with the length $l_{c a}$, is:

$$
n_{c a}=n_{c} \cdot \frac{l_{c a}}{w_{c}}, \text { in shifts }
$$

or

$$
n_{c a}=0.144 \cdot l_{c a} \cdot \frac{m}{\sin \alpha}+0.036 \cdot l_{c a} \cdot \frac{m}{\sin \alpha} \cdot h_{b}+0.144 \cdot l_{c a} \cdot h_{b}+4.59, \text { in shifts }
$$

Taking into account the previous relations, the labour cost in the coal face can be determined:

$$
\sum M_{m r}=n_{c a} \cdot S_{m a}, \text { in lei }
$$

$S_{m a}$ represents the direct salaries of the workers from the coal face, in lei; $n_{c a}$ - total number of the shifts necessary to mine the entire panel coal reserve.

The effective salaries, including the other wages, are:

$$
S_{m a}^{1}=2.185 \cdot S_{m a}, \text { in lei/shift }
$$

Thus, the labour cost is:

$$
\begin{gathered}
M_{m a}=n_{c a} \cdot S_{m a}^{1}=2.185 \cdot n_{c a} \cdot S_{m a}, \text { in lei } \\
\sum M=\left(\begin{array}{l}
0.314 \cdot l_{c a} \cdot \frac{m}{\sin \alpha}+0.078 \cdot l_{c a} \cdot \frac{m}{\sin \alpha} \cdot h_{b}+ \\
+0.314 \cdot l_{c a} \cdot h_{b}+10.02
\end{array}\right) \cdot S_{m a}, \text { in lei }
\end{gathered}
$$

\subsection{Determination of the coal production process time}

It is necessary to take into account the complexity of the coal production process. In this way, the operations in the coal face production process could be grouped as following: the operations developed only along the coal face line, the operations developed only along the top coal caving line and operations superposed on the first two groups, but which does not influence the 


\section{4}

production time cycle. Thus, the time of coal production cycle $T_{c}$, into a top coal caving face, is expressed by the formula (Chiril, 2001; Onica \& Chiril, 2005):

$$
T_{c}=\sum_{i=1}^{l} t_{f i}+\sum_{j=1}^{m} t_{s j}+\sum_{k=1}^{q} t_{b k}+\sum_{p=1}^{r} t_{p}, \text { in minutes }
$$

Where:

$\sum_{i=1}^{l} t_{f i}-\begin{aligned} & \text { represents the specific time of the repeatable and non-superposed operations, only } \\ & \text { along the coal face level; }\end{aligned}$ $\sum_{j=1}^{m} t_{s j}-\begin{aligned} & \text { repeatable operations, superposed at the level of coal face line and top coal caving } \\ & \text { line; }\end{aligned}$ $\sum_{k=1}^{q} t_{b k}-$ repeatable and non-superposed operations along the top coal caving line; $\sum_{p=1}^{r} t_{p}-$ non-repeatable operations time.

$l, m, q, r-$ operations number afferents to the previous categories.

After a complex analysis of the coal production process, the effective time of production process for coal face advancement with a step equal to $w_{c}=1.25 \mathrm{~m}$, is calculated with the relation:

$$
T_{c}=66.02 \cdot \frac{m}{\sin \alpha} \cdot \frac{1}{n}+5.51 \cdot \frac{m}{\sin \alpha} \cdot h_{b}+22.06 \cdot h_{b}+\frac{2067.11}{n}, \text { in minutes }
$$

Where: $n$ is the worker number in the coal face.

The advancement daily speed of the coal face is determinated with the relation:

$$
w_{m}=\frac{w_{c}}{T_{c}^{w}}, \text { in } \mathrm{m} / \text { day }
$$

Where: $T_{c}{ }^{w}$ represents the production time of cycle, expressed in days.

$$
\begin{gathered}
T_{c}^{w}=\frac{T_{c}}{1440}, \text { in days } \\
T_{c}^{w}=0.045 \cdot \frac{m}{\sin \alpha} \cdot \frac{1}{n}+0.0038 \cdot \frac{m}{\sin \alpha} \cdot h_{b}+0.015 \cdot h_{b}+1.435 \cdot \frac{1}{n}
\end{gathered}
$$

Thus:

$$
\frac{1}{v_{m}}=0.036 \cdot \frac{m}{\sin \alpha} \cdot \frac{1}{n}+0.003 \cdot \frac{m}{\sin \alpha} \cdot h_{b}+0.012 \cdot h_{b}+1.148 \cdot \frac{1}{n}, \text { in days }
$$




\subsection{Cost of energy}

The cost of energy is expressed by the relation:

$$
\sum E=E_{e t}+E_{e T}+E_{e s}, \text { in lei }
$$

Where: $E_{e t}$ represents the cost of energy for coal production transport; $E_{e s}-$ cost of energy for coal face supports; $E_{e t}-$ cost of energy for coal face cutting.

\subsubsection{Cost of energy for coal production transport}

It is calculated with the relation:

$$
E_{e t}=c_{e} \cdot T_{f t} \cdot \sum n_{t i} \cdot P_{t i}, \text { in lei }
$$

Where: $c_{e}$ represents the price of $1 \mathrm{kWh}$ of electric power; $T_{f t}$ - operation time of the conveyors for the entire panel coal reserve; $n_{t i}$ - conveyors number; $P_{t i}-$ conveyors installed power.

$$
E_{e t}=c_{e} \cdot l_{c a} \cdot \frac{m}{\sin \alpha} \cdot \frac{\left(h_{a b}+h_{b}\right)}{k_{u}} \cdot\left(\frac{n_{1} \cdot P_{t a}}{Q_{t a}}+\frac{P_{t g}}{Q_{t g}}\right), \text { in lei }
$$

Where: $k_{u}$ is the utilisation coefficient of the conveyor; $Q_{t g}, Q_{t a}$ - technical capacity of the gallery conveyor, respectively face conveyor; $P_{t g}, P_{t a}$ - installed power of the gallery conveyor, respectively face conveyor.

\subsubsection{Cost of energy for coal face cutting}

$$
E_{e T}=c_{e} \cdot P_{k a} \cdot l_{c a} \cdot \frac{m}{\sin \alpha} \cdot \frac{h_{a b}}{v \cdot b}, \text { in lei }
$$

Where: $v$ is the cutting speed of the shearer; $b$ - cutting strip width of the shearer; $P_{k a}-$ shearer installed power.

\subsubsection{Cost of energy for coal face supports}

$$
E_{e s}=c_{e} \cdot P_{a h} \cdot l_{c a} \cdot \frac{m}{\sin \alpha} \cdot \frac{t_{1}}{d \cdot b \cdot k_{s}}, \text { in lei }
$$

Where: $d$ is the width of the powered support unit; $t_{1}$ - operation time of the hydraulic plant; $k_{s}$ - simultaneity coefficient; $P_{a h}$ - electric motor power of the hydraulic plant of the powered supports. 
Thus, the energy cost is the sum of the previous three categories:

$$
\sum E_{e e}=c_{e} \cdot l_{c a} \cdot \frac{m}{\sin \alpha} \cdot\left[\begin{array}{l}
\frac{\left(h_{a b}+h_{b}\right)}{k_{u}} \cdot\left(\frac{P_{t g}}{Q_{t g}}+\frac{n_{1} \cdot P_{t a}}{Q_{t a}}\right)+ \\
+P_{k a} \cdot \frac{h_{a b}}{v \cdot b}+P_{a h} \cdot \frac{t_{1}}{d \cdot b \cdot k_{s}}
\end{array}\right], \text { in lei }
$$

\subsection{Auxiliary costs}

\subsubsection{Maintenance costs}

From practical experience, the maintenance costs are about $10 \%$ from the depreciation value of the equipments used in the production process. Thus:

$$
A_{r}=0.1 \cdot \sum U_{i}, \text { in lei }
$$

Replacing the equipment value, the previous relation becomes:

$$
\begin{aligned}
A_{r}= & 3.9 \cdot 10^{-4} \cdot \frac{l_{c a}}{v_{m}} \cdot\left(\frac{k_{u t}}{d_{1}}+\frac{n_{1} \cdot k_{t a}+k_{t g}}{d_{3}}\right)+ \\
& +4.88 \cdot 10^{-4} \cdot \frac{l_{c a}}{v_{m}} \cdot \frac{m}{\sin \alpha} \cdot \frac{k_{c s}}{d_{2}} \quad \text {, in lei }
\end{aligned}
$$

\subsubsection{Materials cost}

Materials costs involve the following materials: wire mesh, wood, explosive materials, etc.

$$
\begin{aligned}
\sum A= & A_{r}+A_{p m}+A_{l}+A_{e x}+A_{c s} \\
= & l_{c a} \cdot\left[65.6 \cdot c_{p m}+3.9 \cdot 10^{-4} \cdot \frac{1}{v_{m}} \cdot\left(\frac{k_{u t}}{d_{1}}+\frac{n_{1} \cdot k_{t a}+k_{t g}}{d_{3}}\right)\right]+ \\
& +l_{c a} \cdot \frac{m}{\sin \alpha} \cdot\left[\begin{array}{l}
8.2 \cdot c_{p m}+0.01 \cdot c_{l} \cdot\left(h_{a b}+h_{b}\right)+ \\
+4.88 \cdot 10^{-4} \cdot \frac{1}{v_{m}} \cdot \frac{k_{c s}}{d_{2}}
\end{array}\right]+12.5 \cdot\left(c_{e x}+c_{c s}\right), \text { in lei }
\end{aligned}
$$

Where: $A_{r}$ represents maintenance costs; $A_{p m}$ - wire mesh costs; $A_{l}$ - wood costs; $A_{e x}$ - explosive costs; $A_{c s}$ - explosive primers costs; $c_{p m}$ - unit cost of wire mesh, in lei $/ \mathrm{m}^{2} ; c_{l}-$ unit cost of the wood, lei $/ \mathrm{m}^{3} ; c_{e x}$ - unit cost of the explosive, in lei $/ \mathrm{kg} ; c_{c s}-$ unit cost of the explosive primer. 


\section{Total cost of the coal panel mining}

The calculus relation of the total cost of coal panel mining, taking into account the relations (1),(2),..,(44), resulting (Onica \& Chiril, 2005; Mihăilescu et al., 2013; Mihăilescu, 2014):

$$
\begin{aligned}
\sum C_{i}= & \sum P+\sum I+\sum U+\sum M+\sum E+\sum A= \\
= & X_{1} \cdot l_{c a}+X_{2} \cdot l_{c a} \cdot \frac{m}{\sin \alpha}+X_{3} \cdot l_{c a} \cdot h_{b}+X_{4} \cdot l_{c a} \cdot \frac{m}{\sin \alpha} \cdot h_{b}+ \\
& +X_{5} \cdot l_{c a} \cdot h_{b} \cdot \frac{1}{\sin \alpha}+X_{6} \cdot l_{c a} \cdot \frac{1}{\sin \alpha}+ \\
& +X_{7} \cdot \frac{m}{\sin \alpha}+X_{8} \cdot l_{c a}^{2}+X_{9} \cdot l_{c a}^{2} \cdot \frac{m}{\sin \alpha}+X_{10} \cdot l_{c a}^{2} \cdot h_{b}+ \\
& +X_{11} \cdot l_{c a}^{2} \cdot \frac{m}{\sin \alpha} \cdot h_{b}+X_{12} \cdot l_{c a}^{2} \cdot \frac{m}{\sin \alpha} \cdot h_{b} \cdot \frac{1}{\sin \alpha}+ \\
& +X_{13} \cdot l_{c a}^{2} \cdot \frac{1}{\sin \alpha}+X_{14} \cdot l_{c a}^{2} \cdot h_{b} \cdot \frac{1}{\sin \alpha}+X_{15} \cdot l_{c a}^{2} \cdot \frac{m}{\sin \alpha} \cdot \frac{1}{\sin \alpha}+ \\
& +X_{16} \cdot l_{c a}^{2} \cdot h_{b}^{2} \cdot \frac{1}{\sin \alpha}+X_{17} \cdot l_{c a}^{2} \cdot \frac{m}{\sin \alpha} \cdot h_{b}^{2} \cdot \frac{1}{\sin \alpha}+ \\
& +X_{18} \cdot l_{c a} \cdot\left(\frac{m}{\sin \alpha}\right)^{2}+X_{19} \cdot l_{c a} \cdot\left(\frac{m}{\sin \alpha}\right)^{2} \cdot h_{b}+X_{20} \cdot\left(\frac{m}{\sin \alpha}\right)^{2}+X_{21}, \text { in lei }
\end{aligned}
$$

The coefficients $X_{1}, X_{2}, \ldots, X_{19}$ are expressed by the following relations:

$$
\begin{aligned}
X_{1}= & 2.33 \cdot k_{g}+4.91 \cdot 10^{-3} \cdot\left(\frac{k_{u t}}{d_{1}}+\frac{n_{1} \cdot k_{t a}+k_{t g}}{d_{3}}\right) \cdot \frac{1}{n}+65.6 \cdot c_{p m} ; \\
X_{2}= & 1.54 \cdot 10^{-4} \cdot\left(\frac{k_{u t}}{d_{1}}+\frac{n_{1} \cdot k_{t a}+k_{t g}}{d_{3}}\right) \cdot \frac{1}{n}+6.15 \cdot 10^{-3} \cdot \frac{k_{c s}}{d_{2}} \cdot \frac{1}{n}+ \\
& +0.314 \cdot S_{m a}+c_{e} \cdot \frac{h_{a b}}{k_{u}} \cdot\left(\frac{P_{t g}}{Q_{t g}}+\frac{n_{1} \cdot P_{t a}}{Q_{t a}}\right)+ \\
& +c_{e} \cdot\left(P_{k a} \frac{h_{a b}}{v \cdot b}+P_{a h} \frac{t_{1}}{d \cdot b \cdot k_{s}}\right)+8.2 \cdot c_{p m}+0.025 \cdot c_{l} ; \\
X_{3}= & 5.14 \cdot 10^{-5}\left(\frac{k_{u t}}{d_{1}}+\frac{n_{1} \cdot k_{t a}+k_{t g}}{d_{3}}\right)+0.314 \cdot S_{m a} ; \\
X_{4}= & c_{e} \cdot \frac{1}{k_{u}} \cdot\left(\frac{P_{t g}}{Q_{t g}}+\frac{n_{1} \cdot P_{t a}}{Q_{t a}}\right)+1.28 \cdot 10^{-5} \cdot\left(\frac{k_{u t}}{d_{1}}+\frac{n_{1} \cdot k_{t a}+k_{t g}}{d_{3}}\right)+ \\
& +0.01 \cdot c_{l}+6.43 \cdot 10^{-5} \cdot \frac{k_{c s}}{d_{2}}+0.078 \cdot S_{m a} ;
\end{aligned}
$$




$$
\begin{aligned}
& X_{5}=0.033 \cdot k_{s} ; \quad X_{6}=0.082 \cdot k_{s} ; \quad X_{7}=k_{p a}+1976.08 ; \\
& X_{8}=7.81 \cdot 10^{-4} \cdot k_{g} \cdot \frac{1}{n} ; \quad X_{9}=2.45 \cdot 10^{-5} \cdot k_{g} \cdot \frac{1}{n} ; \quad X_{10}=8.17 \cdot 10^{-6} \cdot k_{g} ; \\
& X_{11}=2.04 \cdot 10^{-6} \cdot k_{g} ; \quad X_{12}=3.56 \cdot 10^{-4} \cdot k_{s} \cdot \frac{1}{n}+7.20 \cdot 10^{-5} \cdot k_{s} ; \\
& X_{13}=0.027 \cdot k_{s} \cdot \frac{1}{n} ; \quad X_{14}=2.88 \cdot 10^{-4} \cdot k_{s}+0.011 \cdot k_{s} \cdot \frac{1}{n} ; \\
& X_{15}=8.64 \cdot 10^{-4} \cdot k_{s} \cdot \frac{1}{n} ; \quad X_{16}=1.18 \cdot 10^{-4} \cdot k_{s} ; \quad X_{17}=2.97 \cdot 10^{-5} \cdot k_{s} ; \\
& X_{18}=1.92 \cdot 10^{-4} \cdot \frac{k_{c s}}{d_{2}} \cdot \frac{1}{n} ; \quad X_{19}=1.60 \cdot 10^{-5} \cdot \frac{k_{c s}}{d_{2}} ; \\
& X_{20}=6.36 ; \quad X_{21}=11343.83+10.02 \cdot S_{m a}
\end{aligned}
$$

\section{Unit cost relation}

Finally, taking into account the previous equations and every element of the costs, the following mathematical model of the unit cost $c\left(l_{c a}, h_{b}\right)$ is obtained, in lei/tonne, as a dependent function (Mihăilescu et al, 2013; Mihăilescu, 2014) - where: the panel length $l_{c a}$ and the top coal height $h_{b}$ are independent and variable parameters; coal seam thickness $m$ and the dip $\alpha$ are the known data, but different in order to the geological conditions of the coal deposit. Also, the unit cost function contains a chain of constants $X_{1}, X_{2}, \ldots, X_{20}$ that results from the different fixed elements of calculation.

$$
\begin{aligned}
& c_{i}=l_{c a} \cdot\left(\frac{X_{8}}{4 \cdot \frac{m}{\sin \alpha}}+\frac{X_{9}}{4}+\frac{X_{10}}{1.6 \cdot \frac{m}{\sin \alpha}}+\frac{X_{11}}{1.6}+\frac{X_{12}}{1.6 \cdot \sin \alpha}+\frac{X_{13}}{4 \cdot m}+\frac{X_{14}}{1.6 \cdot m}+\frac{X_{15}}{4 \cdot m}\right)+ \\
& +h_{b} \cdot\left(\frac{X_{3}}{4 \cdot \frac{m}{\sin \alpha}}+\frac{X_{4}}{4}+\frac{X_{5}}{4 \cdot m}+\frac{X_{19} \cdot \frac{m}{\sin \alpha}}{4}\right)+\frac{1}{l_{c a}} \cdot\left(\frac{X_{7}}{4}+\frac{X_{20}}{4}+\frac{X_{21}}{4 \cdot \frac{m}{\sin \alpha}}\right)+ \\
& +\frac{1}{h_{b}} \cdot\left(\frac{X_{1}}{1.6 \cdot \frac{m}{\sin \alpha}}+\frac{X_{2}}{1.6}+\frac{X_{6}}{1.6 \cdot m}+\frac{X_{18} \cdot \frac{m}{\sin \alpha}}{1.6}\right)+ \\
& +\frac{l_{c a}}{h_{b}} \cdot\left(\frac{X_{8}}{1.6 \cdot \frac{m}{\sin \alpha}}+\frac{X_{9}}{1.6}+\frac{X_{13}}{1.6 \cdot m}+\frac{X_{15}}{1.6 \cdot \sin \alpha}\right)+\frac{1}{l_{c a} \cdot h_{b}} \cdot\left(\frac{X_{7}}{1.6}+\frac{X_{20}}{1.6}+\frac{X_{21}}{1.6 \cdot \frac{m}{\sin \alpha}}\right)+
\end{aligned}
$$




$$
\begin{aligned}
& +l_{c a} \cdot h_{b} \cdot\left(\frac{X_{10}}{4 \cdot \frac{m}{\sin \alpha}}+\frac{X_{11}}{4}+\frac{X_{12}}{4 \cdot m}+\frac{X_{14}}{4 \cdot m}+\frac{X_{16}}{1.6 \cdot m}+\frac{X_{17}}{1.6 \cdot m}\right)+l_{c a} \cdot h_{b}^{2} \cdot\left(\frac{X_{16}}{4 \cdot m}+\frac{X_{17}}{4 \cdot \sin \alpha}\right)+ \\
& +\left(\frac{X_{1}}{4 \cdot \frac{m}{\sin \alpha}}+\frac{X_{2}}{4}+\frac{X_{3}}{1.6 \cdot \frac{m}{\sin \alpha}}+\frac{X_{4}}{1.6}+\frac{X_{5}}{1.6 \cdot m}+\frac{X_{6}}{4 \cdot m}+\frac{X_{18} \cdot \frac{m}{\sin \alpha}}{4}+\frac{X_{19} \cdot \frac{m}{\sin \alpha}}{1.6}\right)
\end{aligned}
$$

in lei/tonne (46)

For this problem solving of the optimization of the mining method parameters, by this method, one must set the condition that the function $c_{i} \equiv C\left(l_{c a}, h_{b}\right)$ have a minimum value, that is the obtained coal tonne cost to be lowest, which means that the partial derivatives of this function, by report to the variables $l_{c a}$ and $h_{b}$ must be zero (Onica\&Chiril, 2005):

$$
\begin{aligned}
& \frac{\partial \sum C\left(l_{c a}, h_{b}\right)}{\partial l_{c a}}=0 \\
& \frac{\partial \sum C\left(l_{c a}, h_{b}\right)}{\partial h_{b}}=0
\end{aligned}
$$

The expressions (47) and (48) compose a system of two equations, with the unknowns $l_{c a}$ and $h_{b}$. Because of the fact that this system is very complex and is not to be solved analytically, it is preferred to make a sensibility analysis of the function by report to the optimization variables (the variants' method).

\section{Data analysis to establish the optimum values of the panel length and the top coal height in function of the unit cost}

The optimum values of the panel length and of the top coal height could be obtained by two methods: a) analytical method (by finding the minimum of the unit cost function); b) variants' method (analyzing the sensitivity of the unit cost function to the optimizing parameters variation) - used in the condition of the technical and economic model (46).

In our case, the input values in the unit cost function (46), are the following: $m=\{17,20$, $25,30,35,40,45,50,55\} \mathrm{m} ; \alpha=\{46,50,55,60,65,70,75\}^{\circ} ; l_{c a}=\{100,200,300,400,500$, $600\} \mathrm{m} ; h_{b}=\{1,2, \ldots, 15\} \mathrm{m}$. Also, a set of number of workers per shift was taken into consideration, so that: $n=\{6,8,10,12,15\}$. In the basis of obtained data, there was provided a series of graphical representations of unit cost variation in function of the studied parameters (Fig. 7-10) (Mihăilescu et al., 2013; Mihăilescu, 2014).

The top coal height value for which are obtained the minimum costs is $h_{\text {boptim }}=4 \mathrm{~m}$, regardless of the coal face length and the workers number. The optimum interval for the application of the mechanized top coal caving mining method, is between the following limits:for $l_{a b}=(20-40)$ $\mathrm{m}, h_{\text {boptim }}=(3-6) \mathrm{m}$; for $l_{a b}=(51-56) \mathrm{m}, h_{b \text { optim }}=(3-5) \mathrm{m}$; for $l_{a b}=(60-78) \mathrm{m}, h_{b \text { optim }}=(2-5) \mathrm{m}$. 
The optimum domain, for the panel length $l_{c a}$, fits in the natural limits of the geological blocks in which the mining method is applied, respectively of (100-600) $\mathrm{m}$; the unit costs varying in this case with the values ranging between 21 lei (for $l_{a b}=20 \mathrm{~m}$ ) and 11 lei (for $l_{a b}=78 \mathrm{~m}$ ). In percents, these are situated in the interval of $2.23 \%$ and $2.83 \%$.

The increase of the coal face length has a major influence on the cost value obtained at the panel level. Thus, increasing the coal face length from $20 \mathrm{~m}$ to $78 \mathrm{~m}$ determine a unit cost reduction with 471 lei/tonne, that is with $\approx 200 \%$.

Also, increasing of number of the working team, from 6 to 15 workers/shift, does not have a significant impact on the cost reduction. The percentage of cost reduction, when 15 workers/ shift exist in the face, by report to 6workers/shift, is a maximum of $2 \%$, for all analyzed coal face lengths. Although the coal face operations are mechanized, the appropriate number of workers placed at the face ends for special operations is very important, to maintain a constant advancement speed of the coal face.
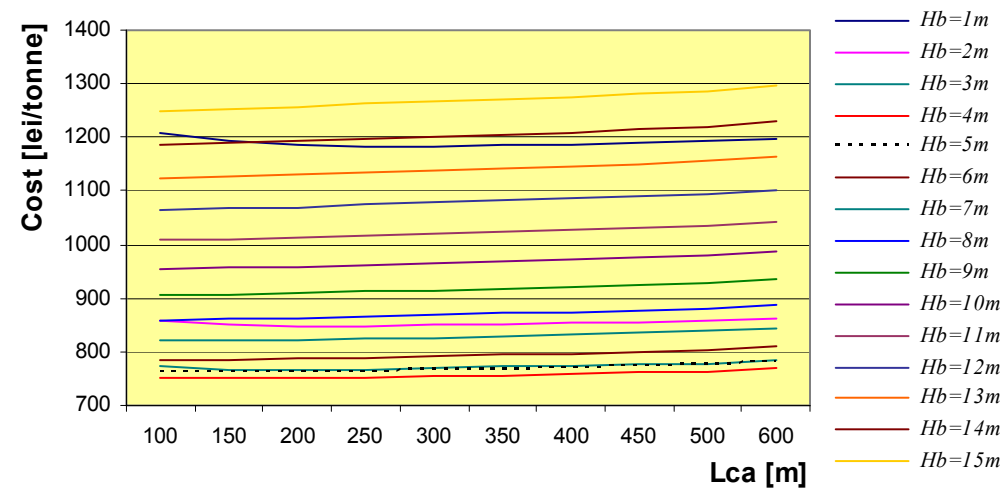

Fig. 7. Variation of the unit costs, for $l_{a b}=30 \mathrm{~m}$ and $N_{\text {shift }}=6$ workers
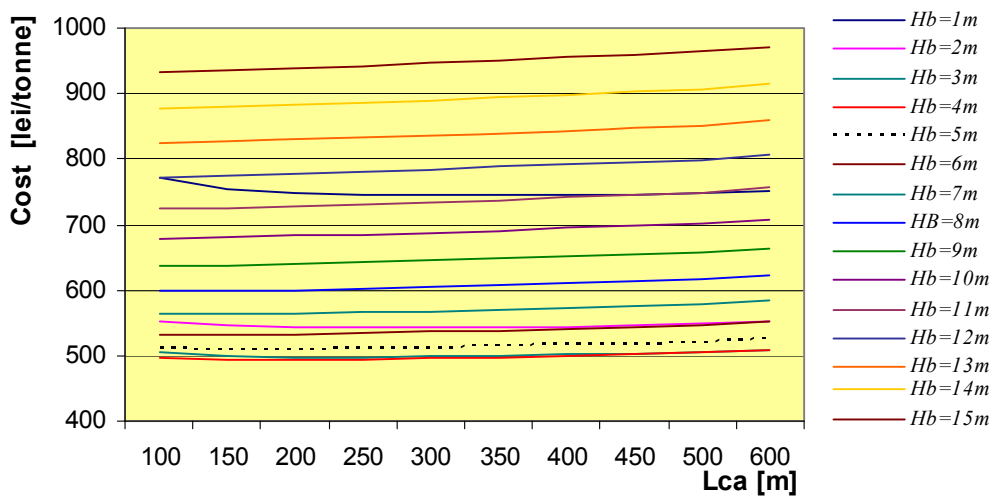

Fig. 8. Variation of the unit costs, for $l_{a b}=60 \mathrm{~m}$ and $N_{\text {shift }}=6$ workers 


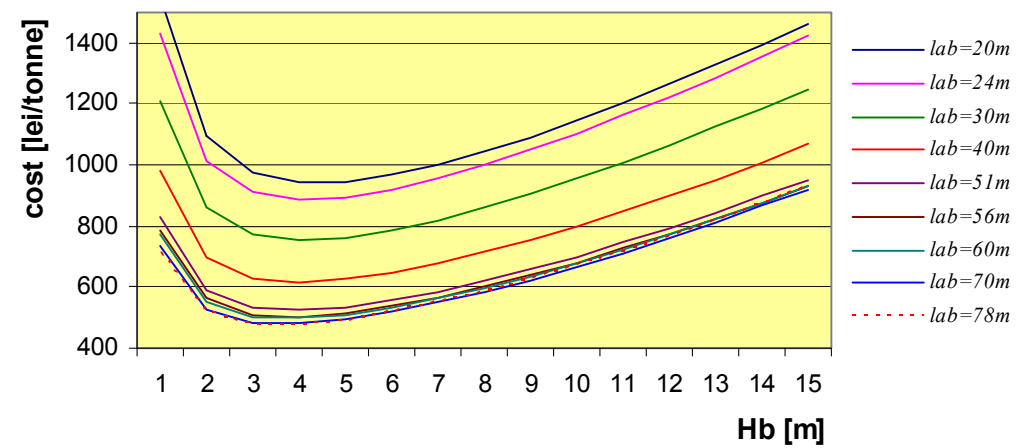

Fig. 9. Variation of the unit costs, for $l_{c a}=100 \mathrm{~m}$ and $N_{\text {shift }}=6$ workers

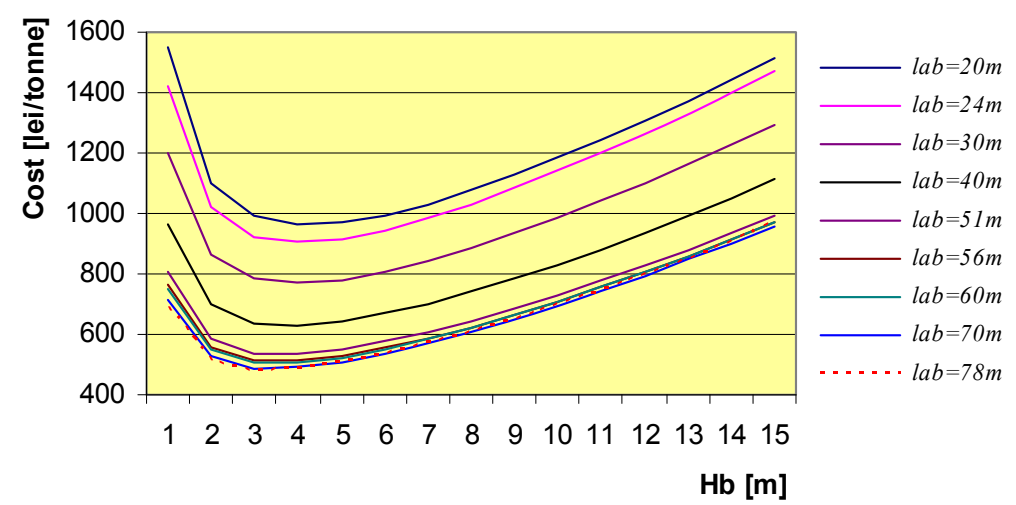

Fig. 10. Variation of the unit costs, for $l_{c a}=600 \mathrm{~m}$ and $N_{\text {shift }}=6$ workers

The top coal height increase, from $3 \mathrm{~m}$ to $15 \mathrm{~m}$, in the case of workers team, with $N_{\text {shift }}=6$ workers, generates a production cycle (Fig. 11 and 12) increasing with up to $265 \%$ (for $l_{a b}=20 \mathrm{~m}$ ), respectively $311.94 \%$ (for $l_{a b}=78 \mathrm{~m}$ ). The coal face cycle duration decreases when in the coal face exists a team of 15 workers/shift, with up to $54.5 \%$ (for $h_{b}=3 \mathrm{~m}$ and $l_{a b}=20 \mathrm{~m}$ ), respectively with $15.34 \%$ (for $h_{b}=3 \mathrm{~m}$ and $l_{a b}=20 \mathrm{~m}$ ), by report to a team with 6 workers $/ \mathrm{shift}$.

The daily advancement speed (Fig. 13) of the coal face decreases at the same time with the top coal height and the coal face length. For a top coal height variation between $3 \mathrm{~m}$ and $10 \mathrm{~m}$, the advancement speed decreases with $265 \%$ (for $l_{a b}=20 \mathrm{~m}$ ), respectively with $312.44 \%$ (for $l_{a b}=78 \mathrm{~m}$ ). Increasing the coal face length, from $20 \mathrm{~m}$ to $78 \mathrm{~m}$, leads to a face speed reduction with $266.143 \%$ (for $h_{b}=3 \mathrm{~m}$ ), respectively with $313.77 \%$ (for $h_{b}=15 \mathrm{~m}$ ). The coal face advancement speed increases when in the coal face exist a number of workers $N_{\text {shift }}=15$, by report to $N_{\text {shift }}=6$, with values ranging between $54.62 \%-39.4 \%$ (for $h_{b}=3 \mathrm{~m}$ and $l_{a b}=20-78 \mathrm{~m}$ ), respectively $15.29 \%-10.22 \%$ (for $h_{b}=3 \mathrm{~m}$ and $l_{a b}=20-78 \mathrm{~m}$ ).

Coal face daily production (Fig. 14 and Fig. 15) increases at the same time with the top coal height, from $3 \mathrm{~m}$ to $15 \mathrm{~m}$, the obtained values belonging to the interval of $19.94 \%$ (for $l_{a b}=20 \mathrm{~m}$ ), respectively $1.98 \%$ (for $l_{a b}=78 \mathrm{~m}$ ). Increasing the coal face length from $20 \mathrm{~m}$ to $78 \mathrm{~m}$ implies a production increase with $46.6 \%$ (for $h_{b}=3 \mathrm{~m}$ ), respectively $24.86 \%$ (for $h_{b}=15 \mathrm{~m}$ ). 


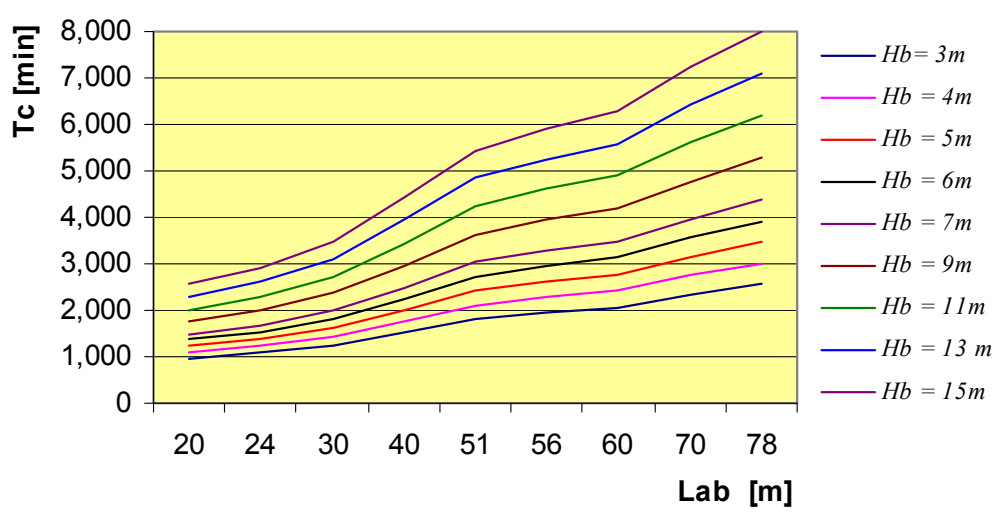

Fig. 11. Variation of the coal face cycle $T_{c}=f\left(l_{a b}\right)$, in function of the coal face length, for $N_{\text {shift }}=6$ workers

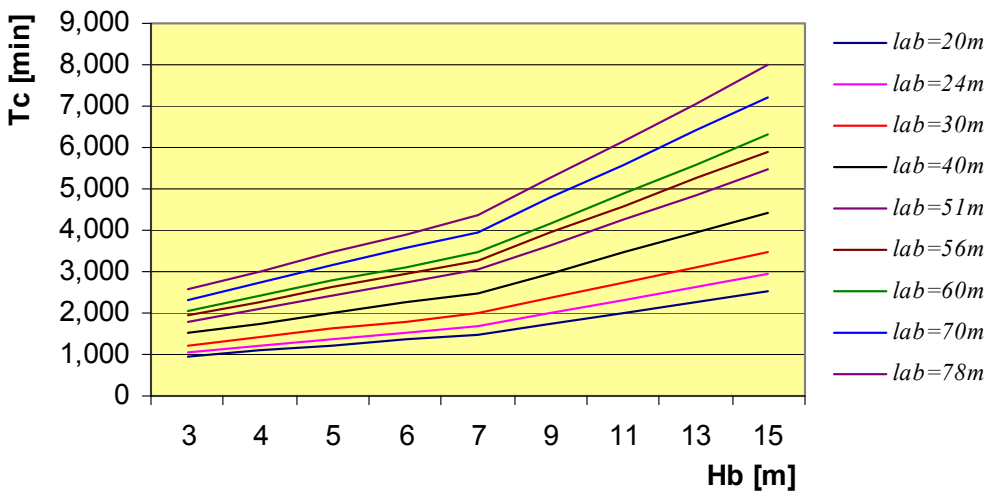

Fig. 12. Variation of the coal face cycle $T_{c}=f\left(h_{b}\right)$, in function of the coal face length, for $N_{\text {shift }}=6$ workers

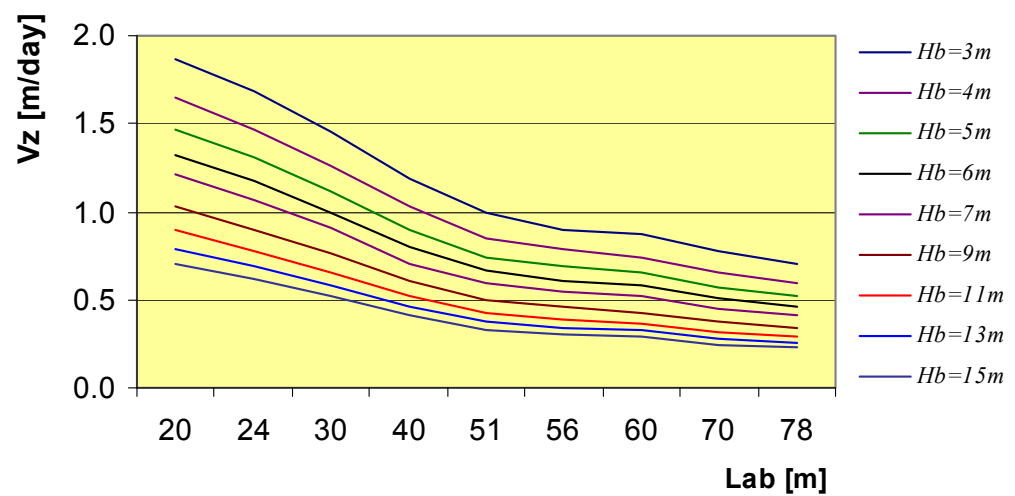

Fig. 13. Variation of the daily face advancement speed $V_{z}=f\left(l_{a b}\right)$, in function of the coal face length, for $N_{\text {shift }}=6$ workers 


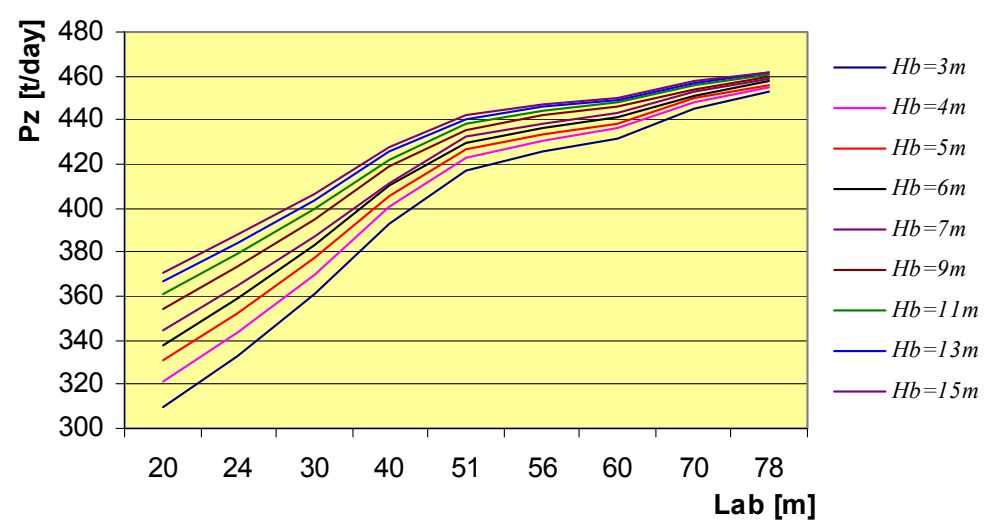

Fig. 14. Variation of the daily coal production $P_{z}=f\left(l_{a b}\right)$, in function of the coal face length, for $N_{\text {shift }}=6$ workers

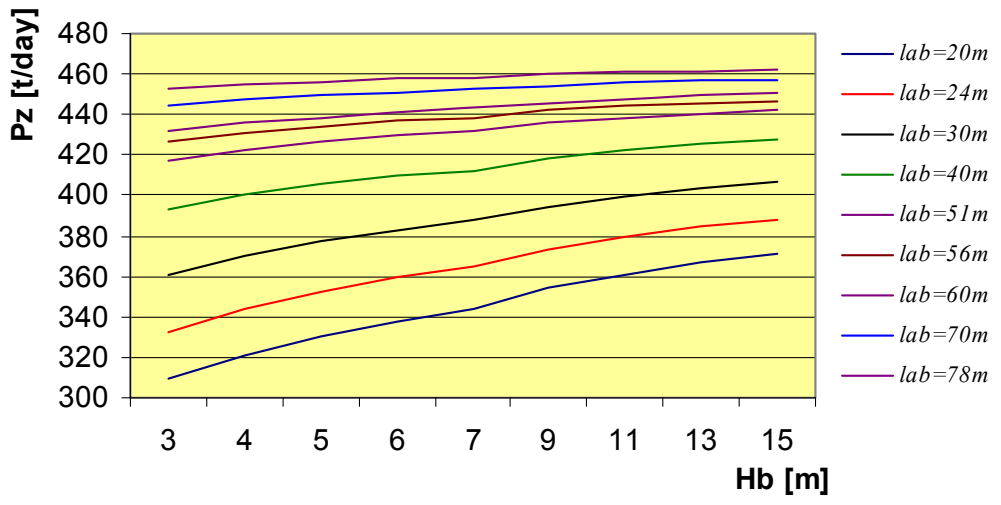

Fig. 15. Variation of the daily coal production $P_{z}=f\left(h_{b}\right)$, in function of the coal face length, for $N_{\text {shift }}=6$ workers
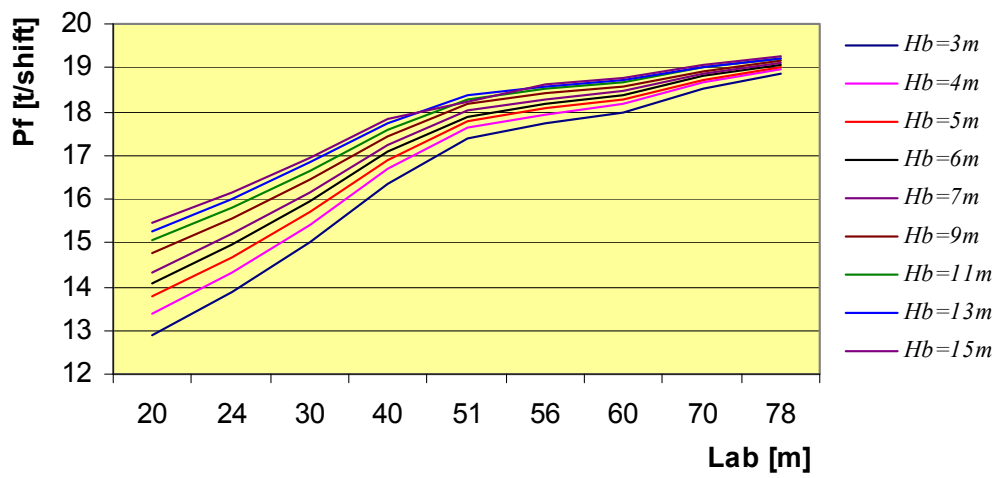

Fig. 16. Variation of the workforce productivity $P_{f}=f\left(l_{a b}\right)$, in function of the coal face length, for $N_{\text {shift }}=6$ workers 
The workers' number growth in the coal face, from 6 to 15 workers/shift, in the conditions of the top coal height increase from $3 \mathrm{~m}$ to $15 \mathrm{~m}$, determine a supplementary coal production of $54.36 \%-15.40 \%$, for $l_{a b}=20 \mathrm{~m}$, respectively $34.8 \%-15.40 \%$, for $l_{a b}=78 \mathrm{~m}$ (the biggest coal production increase are obtained for the smallest top coal heights).

Workforce productivity (Fig. 16) has the same increasing tendency as the extracted production, for the same workers number placed in the coal face. Thus, the growing the top coal height from $3 \mathrm{~m}$ to $15 \mathrm{~m}$ has as impact the workforce productivity increasing with $20 \%$ (for $l_{a b}=20 \mathrm{~m}$ ), respectively $1.95 \%$ (for $l_{a b}=78 \mathrm{~m}$ ). Increasing the coal face length, from $20 \mathrm{~m}$ to $78 \mathrm{~m}$, generates a workforce productivity increase with $46.54 \%$ (for $h_{b}=3 \mathrm{~m}$ ), respectively $24.5 \%$ (for $h_{b}=3 \mathrm{~m}$ ) and $N_{\text {shift }}=6$.

Supplementation of the number of workers in the coal face, from 6 to 25 workers/shift, in the conditions of top coal height increase, from $3 \mathrm{~m}$ to $15 \mathrm{~m}$, does not have as effect the workforce productivity growth. Even if the coal production is bigger, the face workers number doubling has as consequence a productivity reduction with values ranging between $61.87 \%$ and $116 \%$ (for $l_{a b}=20 \mathrm{~m}$ ), respectively $79.52 \%$ and $127.38 \%$ (for $l_{a b}=78 \mathrm{~m}$ ).

\section{Conclusions}

The necessity to improve the economic-financial results of the Jiu Valley coal mining in the conditions of the continuously reducing, until completely eliminated public support, the very difficult conditions of the coal seams have imposed the necessity of replacing the classical mining methods with the new mining methods and technologies more efficiently from the point of view of technical and economic indicators.

In this way, the interests of specialists were focused in two directions: first direction, involving the modernization of the faces by using the complex mechanized longwall mining; second direction, introducing the new mining methods that ensure the coal production concentration at the panel level, respectively the top coal caving mining methods.

In the Jiu Valley conditions, the application of the top coal mining methods led to an important increase of the face productivity, by report to the classical mining methods.

To increase the technical and economic performances of faces, in horizontal slices, in Jiu Valley hard coal basin, the top coal caving mining method (Bourbaki mining method) was adopted. This method was experimented using classic technology (individual supports - hydraulic props and articulated caps and coal cutting by drilling-blasting).

In view to improve the work safety, coal recovery and decrease the dilution rate, it is planned to introduce the mechanized mining technology, using the frame powered supports and coal cutting by shearers.

The goal of this study is to make a technical and economic analysis of the top coal caving mining method and technology to find the optimum values of the panel length and the top coal height for a minimum cost of production. Therefore, the following stages have been completed: a) the coal face technological process was analyzed in detail and the relation for the production cycle and daily face advancement speed was determined; b) there was established the technological unit for optimization "top coal caving face", economic mathematical model and the purpose function as minimum cost; c) for the economic model, the general costs and specific costs equations were established; d) the optimization of the independent parameters was obtained by a sensibility analysis of the technical and economic model. 
The main parameters optimization of the mechanized top coal caving face, in horizontal slices, has been achieved by analysing the general cost function, generated at the panel level.

The optimum value of the top coal height, for a minimum unit cost, is of $h_{b \text { optim }}=4 \mathrm{~m}$ (in the domain of 2-6 m, for $\pm 5 \%$ cost deviation), regardless of the coal face length and the face workers' number.

The optimum domain of the panel length $l_{c a}$ is framed in between the natural geological blocks limits, respectively of (100-600) $\mathrm{m}$.

Increasing the coal face length has a major influence on the cost values obtained at the coal face level.

The growth of the workers' number of the face team, from 6 to 15 workers/shift, does not have a significant impact on the cost reduction, but has as effect the production time cycle reduction (which increases at the same time with top coal caving height).

The daily advancement speed of the coal face diminishes at the same time with the top coal height and coal face length decrease.

The daily production and the workforce productivity, at the coal face level, grow with the top coal height increase.

\section{References}

Almăşan B., 1984. Mining of Romanian mineral resources deposits, Tom I (in Romanian), Technical Publishing House, Bucharest, pp. 70-291.

Andrioni F., Goian C., 2012. Profile of Social Services from Jiu Valley in Light Professionals perception. Qualitative approach. [In:] Annals of the University of Petroşani, Economics, 12(3), p. 5-16.

Andrioni F., Schmidt M., 2011. Economic and social problems from the Jiu Valley and the need for development support network for elderly people from Petrosani. [In:] Annals of the University of Petroşani, Economics, 11(2), p. 25-32.

Chiril G., 2001. Optimization of the main technological parameters of the top coal caving mining methods, applied in the thick and gentle dip coal seams of Jiu Valley. Ph.D. Thesis, University of Petroşani, $194 \mathrm{p}$ (in Romanian).

Covaci St., 1983. Underground mining, Tom I. Didactical and Pedagogical Publishing House, Bucharest, 424 p (in Romanian).

Jaszczuk M., Kania J., 2008, Coal production costs components and coal price as crucial factors in the designation of coal output. Arch. Min. Sci., Vol. 53, No 2, p. 183-214.

Jonek-Kowalska I., 2012. Cost analysis and assessment in the Polish hard coal mining industry in years 2006-2011. Ad Alta, Vol. 2, Iss. 2, p. 35-40.

Jonek-Kowalsa I., 2013. Introduction to a methodology of cost management in a colliery from a perspective of longwall life cycle. Eur. Sci. J., Vol 9, No 25, p. 380-402.

Jonek-Kowalska I., Turek M., 2013. Cost rationalisation of maintaining post-industrial regions. Pol. J. Environ. Stud., Vol. 22, No 3, p. 727-740.

Mihăilescu V., 2014. Improvement of the mining methods in the case of the thick and dip coal seams applied in the Jiu Valley mining basin. Ph.D.Thesis, Petroşani, 294 p (in Romanian).

Mihăilescu V., Onica I., Cozma E., 2012. Parameters'optimization of the longwall faces with top coal caving mining, in horizontal slices and individual support technology. Annals of the University of Petroşani - Mining Engineering, p. 51-62.

Mihăilescu V., Onica I., Cozma E., 2013. Technical and economic optimization of the mechanized longwall faces with top coal caving mining, in horizontal slices. Mining Revue, No. 2, p. 31-38. 


\section{6}

Onica I., 1990. Self-financing ways of the Jiu Valley coal basin mining. Mining Revue, Vol. 41, No. 8, p. $362-371$ (in Romanian).

Onica I., 1995. Improvement of longwall mining technologies by using the adequate powered supports, in the Jiu Valley coal basin (in Romanian), PhD Thesis, University of Petroşani, $156 \mathrm{p}$.

Onica I., Chiril G., 2005. Top coal mining in longwall faces. AGIR Publishing House, Bucureşti, 291 p. (in Romanian).

Onica I., Cozma E., Mihăilescu V., 2011. Improvement of economic efficiency of longwall mining in short panels in the case of Jiu Valley thick coal seams, Romania. Proceedings of the International Multidisciplinary Scientific Geoconference, SGEM 2011, 20-25 June, Sofia-Bulgaria, 2011, Published by STEF92 Technology Ltd. Sofia-Bulgaria, DOI: $10.5593 /$ sgem2011, p. 801-808.

Onica I., Marian D., 2012. Ground surface subsidence as effect of underground mining of the thick coal seams in the Jiu Valley basin. Arch. Min. Sci., Vol. 57, No 3, p. 499-529. DOI 10.2478/v10267-012-0017-2. 